\title{
25 Resarch Square \\ Detection of Brucella abortus and Brucellla melitensis in cattle and sheep from southern Cameroon
}

\author{
Kamga Ndefo Rolin Mitterran \\ University of Dschang \\ Silatsa Assongo Barberine \\ Universite de Dschang \\ Farikou Oumarou \\ University of Bamenda \\ Gustave Simo ( $\nabla$ gsimoca@yahoo.fr) \\ Universite de Dschang https://orcid.org/0000-0002-0449-818X
}

\section{Research article}

Keywords: Cattle, sheep, B. abortus, B. melitesis, Cameroon

Posted Date: April 20th, 2020

DOI: https://doi.org/10.21203/rs.3.rs-21575/v1

License: (c) (i) This work is licensed under a Creative Commons Attribution 4.0 International License. Read Full License 


\section{Abstract}

Background: Brucellosis is an infectious disease caused by bacterial of the genus Brucella. Although several investigations detected Brucella antibodies in many animal species, low attention has been paid for specific identification of different Brucella species in animals of Sub-Saharan African counties. It is in this light that this study was designed to identify Brucella abortus and Brucellla melitensis in cattle and sheep of several villages of southern Cameroon in order to improve our epidemiological knowledge on brucellosis in central Africa

Methods: Blood samples were collected in 597 cattle and 315 sheep of 15 villages of two regions of Cameroon. DNA was extracted from blood samples and primers amplifying bcsp31 gene enabled the identification of Brucella spp infections in domestic animals. Amongst animals found with Brucella spp infections, specific primes were used to identify $B$. abortus and $B$. melitensis respectively.

Results: From 912 animals analyzed in this study, 159 (17\%) were found with Brucella infections. This gives an infection rate of 20.93\% (125/597) in cattle and 10.79\% (34/315) in sheep respectively. Of the 159 animals harboring Brucella infections, 118 (12.93\%) were infected by B. abortus and 29 (3.17\%) by B. melitensis. The Brucella infection rate $(20.56 \%)$ was high in animals of the Noun division compared to those $(12.35 \%)$ of Yoko. Between animal species, significant differences were observed in infection rates of both abortus and $B$. melitensis. The difference in the $B$. abortus infection rates remains significant between Yoko and Noun, and especially between villages of the Noun division.

Conclusion: This study revealed for the first time B. melitensis and $B$. abortus infections in cattle and sheep of the Noun and Yoko in the southern Cameroon. The identification of $B$. melitensis and $B$. abortus in animals suggests further investigations on human brucellosis. Results of this study highlight the need of developing and implementing control measures against brucellosis in Cameroon, especially in villages presenting high risk for Brucella infections.

\section{Introduction}

Brucellosis is one of the most widespread zoonotic infectious diseases in the world [1]. It is caused by bacteria of the genus Brucella which contains six species notably Brucella abortus, $B$. melitensis, $B$. suis, $B$. ovis, $B$. canis and $B$. neotomae [2, 3]. This infectious disease is among the top thirteen neglected zoonotic and contagious diseases. Brucella infections are also considered as one of the major threat for livestock production in developing countries $[4,5,6]$. Human and several animal species including cattle, small ruminants, pigs, rodents and carnivores have been reported with Brucella infections $[2,7]$. Amongst the six Brucella species, $B$. abortus, $B$. melitensis and $B$. suis have impacts on domestic livestock productivity and human health [8]. In animals, Brucella infections induce abortion, infertility and the reduction of milk yield while in human, they cause long debilitating illnesses [9]. In sub-Saharan African countries, the economic losses resulting from Brucella infections in livestock can be estimated to about 427 million US\$ per year for livestock [9]. Although various human and domestic animals can be infected by different Brucella species, little attention has been paid for Brucella infections in developing countries due its neglected aspect.

In most sub-Saharan African countries, investigations undertaken on brucellosis have been mainly based on Brucella antibodies detection using various serological tests like the Rose Bengal Plate Test (RBPT), Enzyme Linked Immunosorbent assay (ELISA), complement fixation test $[7,10,11,12,13,14]$. Even though serological tests have generated epidemiological data on the sero-prevalence of Brucella antibodies in humans and domestic animals of several sub-Saharan countries, these tests cannot differentiate different Brucella species $[7,10,11,13]$. Moreover, the host species for each Brucella species remain not well known. In consequence, results generated by these immunological tests are of limited epidemiological values. The distribution and the transmission dynamics of different Brucella species remain therefore not well understood. Up till now, data regarding the prevalence of different Brucella species are still 
lacking in most sub-Saharan countries. Accurate identification of strains circulating in different hosts is a prerequisite for the improvement of our epidemiological knowledge of brucellosis.

Although the methods based on the culture and isolation of Brucella have been considered as the gold standard for brucellosis diagnosis [15], these methods are tedious, time consuming and difficult to perform in developing countries [16]. To overcome these challenges, molecular tools have been developed to facilitate the identification of different Brucella species $[17,18,19]$.

These molecular tools appeared reliable, simple, easy to perform and are able to identify natural infections of different Brucella species $[7,17,18,20,21,22]$. Their use in West and East Africa enabled the identification and characterization of different Brucella species [7, 21, 23, 24]. However, most studies performed in central Africa have been focused on Brucella antibodies detection and consequently, the Brucella species that infects humans and different animal species are still unknown. Specific identification of different Brucella species could help to understand the circulation and spread of each species, and also the current epidemiological situation of brucellosis in each setting.

The present study was designed to identify Brucella abortus and Brucellla melitensis in cattle and sheep of several villages of southern Cameroon in order to improve our epidemiological knowledge on brucellosis in central Africa.

\section{Materials And Methods}

\section{Study design and description of the study areas}

This cross-sectional study was conducted in nine villages (Foumban, Foumbot, Njimom, Massangam, Magba, Malentuen, Koutaba, Bangourain and Kouptamo) of the Noun division of the west region and six villages (Lena, Ngoun, Yoko Wankou, Megan, Kong and Kounde) of Yoko in the center region of Cameroon. The first survey was performed in November 2017 at Yoko and the second one from April to June 2018 in the Noun Division.

Yoko $\left(5^{\circ} 31^{\prime} 60^{\prime \prime} \mathrm{N} ; 12^{\circ} 18^{\prime} 57^{\prime \prime} \mathrm{E}\right)$ is located in the "Mbam et Kim" Division of the center region of Cameroon. At about 270 $\mathrm{km}$ in the northeast of Yaoundé, (capital of Cameroon), this locality covers about $15000 \mathrm{~km}^{2}$ (Figure 1). Yoko is located between the southern green part and the northern Sahelian part of the country. It is recognized as the large basin for cattle and small ruminant's production of the center region of Cameroon. Moreover, the presence of pasture and water for animals breeding favors transhumance of herds originating from Western, Eastern and Adamawa regions of Cameroon. This transhumance phenomenon occurs also for herds from neighboring countries like the Central Africa Republic [25, 26].

The Noun division $\left(4^{\circ} 95^{\prime} 6^{\circ} 30^{\prime} \mathrm{N} ; 10^{\circ} 30^{\prime} 12^{\circ} \mathrm{E}\right.$ ) is located in the western highlands of Cameroon. It covers about $7687 \mathrm{~km}^{2}$ with a vegetation characterized by the savannah and degraded forest (Figure 1). Due to its climatic conditions that are favorable for cattle and small ruminant breeding, the Noun division is considered as the main cattle production area of the west region of Cameroon [27]. For trade or transhumance purposes, animals of these localities can move to other regions such as the Northwest, the Center and the Adamawa regions of Cameroon.

The cattle reared at Yoko and in the Noun division are indigenous breeds made of Zebu Goudali, Zebu White Fulani and Zebu Red Fulani with few cross breeds [27]. In these two localities, various animal species including goats, sheep and cattle share the same environment. The feeding system observed in these localities is essentially free grazing and sometime, associated to stall-feeding.

\section{Ethics statement}


The protocol of this study was approved by the Ministry of livestock, fisheries and animals Industries of Cameroon with the reference number $N^{\circ} 015 / 16 / L / D D E P I A . N N$. The review board of the molecular parasitology and entomology subunit of the Department of Biochemistry of the Faculty of Science of the University of Dschang gave also its approval. The local administration and traditional authorities of each sampling site were informed and their approvals were obtained. Verbal consent was obtained from each owner, after detailed explanation of the objective of the study.

\section{Sample size estimation}

The prevalence of $B$. abortus and B. melitensis was determined in cattle and sheep of 15 villages of Southern Cameroon. For this study, a stratified sampling strategy was applied to select herds and individual cattle per herd. The sample size was estimated for cattle using a standard formula for cross-sectional studies as described by Thrusfield [28];

$$
n=Z^{2} P \exp (1-P \exp ) / L^{2}
$$

where $n=$ the minimum sample size required, $Z=$ the critical value for a given confidence interval which is 1.96 at $95 \%$ confidence interval, $\mathrm{P}=$ expected prevalence and $\mathrm{L}=$ margin of error (the margin of error is 0.05$)$ ).

The prevalence of brucellosis was assumed to $5.2 \%$ as reported from study previously undertaken in the North West Region of Cameroon [27]. In each herd and depending on its size, at least $20 \%$ of cattle were sampled. More than $20 \%$ of cattle of some herds were sampled for specific reasons like the interests and cooperation of some farmers and advices from veterinarians. Selection of individual cattle to be sampled from each chosen herd was based on a systematic random sampling technique as described by Asgedom et al. [29]. A total of thirty-seven (37) farms were enrolled in fifteen (15) villages for a sample size of 597 cattle.

For the sheep, where there is no published data on the brucellosis prevalence in Cameroon, a prevalence of $50 \%$ was used for the sampling size estimation. Due to the small number of sheep in each village, all of them were sampled irrespective of the number of animals presented by each household. In consequence 315 sheep were sampled from the two agro-ecological zone of southern Cameroon.

\section{Blood collection and DNA preparation}

After approval from each herd owner, the farm characteristics and information regarding each animal including the name of the village (where each sample was collected), the geographical coordinates of each sampling site, the animal species found in farm (cattle, goat, sheep), the origin, sex, age, breed and the feeding system were recorded. Thereafter, about 5 $\mathrm{ml}$ of blood were collected from the jugular vein of sheep and cattle into EDTA coated tubes by a veterinarian. The tubes were labelled and carefully packed to avoid crossed contamination. In the field, the blood samples were stored at $4^{\circ} \mathrm{C}$ in an electric cooler before being transported to the laboratory where they were kept at $-20^{\circ} \mathrm{C}$.

Genomic DNA was extracted from whole blood using the cetyl trimethylammonium bromide (CTAB) method adopted from Navajas et al. [30]. Briefly, frozen samples were thawed and $500 \mu \mathrm{L}$ of whole blood were pipetted into a micro-tube containing $1 \mathrm{~mL}$ of sterile water. The micro-tube was vigorously vortexed and then, centrifuged at $10.000 \mathrm{rpm}$ for $5 \mathrm{~min}$. To the resulting pellet, $500 \mu \mathrm{L}$ of CTAB buffer (CTAB 2\%; $1 \mathrm{M}$ Tris, $\mathrm{pH} 8 ; 0.5 \mathrm{M} \mathrm{EDTA} \mathrm{pH} 8 ; 1.4 \mathrm{M} \mathrm{NaCl}$ ) were added. The pellet was re-suspended and incubated in a water bath at $60^{\circ} \mathrm{C}$ for $30 \mathrm{~min}$. To the content of each micro-tube, $600 \mu \mathrm{L}$ of chloroform/isoamyl alcohol (24/1) mixture was added. Each micro-tube was slowly homogenized for 15 min and the upper aqueous phase was removed and transferred to a new micro-tube of $1.5 \mathrm{~mL}$. DNA was precipitated by adding 600 $\mu \mathrm{L}$ of isopropanol. The mixture was gently homogenized for $5 \mathrm{~min}$ and then incubated overnight at $-20^{\circ} \mathrm{C}$. Thereafter, each micro-tube was centrifuged at 13,000 rpm for $15 \mathrm{~min}$. DNA pellet was then washed twice with cold $70 \%$ ethanol and dried overnight at room temperature. The resulting DNA pellet was re-suspended in $50 \mu \mathrm{L}$ of sterile nuclease free water and then stored at $-20^{\circ} \mathrm{C}$ until use. 


\section{Detection of Brucella spp}

The identification of bacteria of the genus Brucella was performed as described by Mitka et al. [20]. This was done using B4 (5'-TGGCTCGGTTGCCAATATCAA-3') and B5 (5'-CGCGCTTGCCTTTCAGGTCTG-3') primers that amplify a DNA fragment of $223 \mathrm{bp}$. This latter corresponds to bcsp31 gene encoding an immunogenic outer membrane protein of 31 $\mathrm{kDa}$ which is conserved in all Brucella species. PCR reactions were performed in a total volume of $25 \mu \mathrm{L}$ containing 10 pmol of each primer, $2.5 \mu \mathrm{L}$ of 10X PCR buffer, $2 \mathrm{mM} \mathrm{MgCl}_{2}, 200 \mathrm{mM}$ of each dNTP, $5 \mu \mathrm{L}$ of DNA template and 0.5 Unit of Q5 high fidelity Taq polymerase (New England Biolab $5 \mathrm{U} / \mu \mathrm{L}$ ). The amplification program consisted of an initial denaturation step at $95^{\circ} \mathrm{C}$ for 5 min followed by 40 amplification cycles made up of a denaturation step at $95^{\circ} \mathrm{C}$ for $30 \mathrm{~s}$, an annealing step at $60^{\circ} \mathrm{C}$ for $30 \mathrm{~s}$ and an extension step at $72^{\circ} \mathrm{C}$ for $45 \mathrm{~s}$. A final extension step was done at $72^{\circ} \mathrm{C}$ for 5 $\min$.

The amplified products were resolved by electrophoresis on $1.5 \%$ agarose gel. The separation was done at 100 volts for $30 \mathrm{~min}$. Subsequently, the gel was stained with ethidium bromide and DNA bands were visualized under ultraviolet light and photographed. Each sample showing a PCR product of approximately $223 \mathrm{bp}$ was considered as positive or having bacteria of the genus Brucella. These samples were selected and subsequently subjected to the identification of different Brucella species.

\section{Specific identification of different Brucella species}

All samples that have shown a DNA fragment of 223 bp corresponding to bcsp31 gene of Brucella genus were subjected to the molecular identification of different Brucella species. This identification was done using AMOS PCR as described by Bricker and Halling [31]. For this identification, three primers were used: the IS711-specific primer (5'- TGC-CGA-TCACTT-AAG-GGC-CTT-CAT-TGC-3') hybridizes the IS711 element that is common to all Brucella species while the two other primers hybridize an adjacent region outside the IS711. The primer with sequence 5'-GAC-GAA-CGG-AAT-TTT-TCC-AATCCC-3' was specific to $B$. abortus while the third one (5'-AAA-TCG-CGT-CCT-TGC-TGG-TCT-GA-3') was specific to $B$. melitensis. During the identification of the different Brucella species, PCR reactions were carried out in a final volume of $25 \mu \mathrm{L}$ containing $10 \mathrm{pmol}$ of each primer, $2.5 \mu \mathrm{l}$ of $10 \mathrm{X}$ PCR buffer, $2 \mathrm{mM} \mathrm{MgCl}, 0.5 \mu \mathrm{L}(200 \mathrm{mM})$ of each dNTPs, $5 \mu \mathrm{L}$ of DNA template and 0.5 units of Taq DNA polymerase (New England Biolab $5 \mathrm{U} / \mathrm{IL}$ ). The amplification program consisted of an initial denaturation step at $95^{\circ} \mathrm{C}$ for 5 minutes followed by 40 cycles of denaturation step at $95^{\circ} \mathrm{C}$ for $30 \mathrm{~s}$, an annealing step at $53^{\circ} \mathrm{C}$ for $30 \mathrm{~s}$; an extension step at $72^{\circ} \mathrm{C}$ for $1 \mathrm{~min}$ and a final extension step at $72^{\circ} \mathrm{C}$ for 5 min.

The amplified products were separated by electrophoresis on $1.5 \%$ agarose gel containing ethidium bromide. This was done at $100 \mathrm{~V}$ for $45 \mathrm{~min}$. After the electrophoresis, the gel was visualized under ultraviolet light and photographed. Samples showing a DNA fragment of $495 \mathrm{bp}$ were considered as harboring $B$. abortus while those with 730 bp were considered as positive for $B$. Melitensis

\section{Statistical analysis}

The statistical analyses were performed using the Statistical Package for Social Sciences (SPSS) for Windows ${ }^{\circledR}$ version 22.0 (SPSS Inc., Chicago, Illinois). Chi-squared tests were used to compare the infection rates of different Brucella species. The difference was considered significant if the p-value was lower than 0.05 .

\section{Results}

\section{Prevalence of Brucella spp infections}

A total of 912 domestic animals including 597 (65.46\%) cattle and 315 (34.54\%) sheep were investigated for the presence of Brucella infections (Table 1). Five hundred and sixty four (61.84\%) of these animals were from the Noun 
division and 348 (38.16\%) from Yoko (Table 2). From the 912 animals tested, the DNA fragment corresponding to the bcsp 31 gene of Brucella was successfully amplified in 159 blood samples; giving thus a Brucella infection rate of 17.43\% [95\% Cl:14.83 - 20.36]: 12.35\% (43/348) at Yoko and 20.56\% (116/564) in the Noun division. This infection rate was significantly $\left(P=0.0015 ; X^{2}=10.07\right)$ high in Noun $(20.56 \%)$ compared to Yoko $(12.35 \%)($ Table 2$)$. The highest infection rate was observed at Foumban (28.76\%), followed by Magba (28.57\%) and Bangourain (23.94\%) (Table 2). The lowest infection rate was observed at Malentouen where no animal was found with Brucella infection (Table 2). Between villages of the Noun division, significant difference $\left(P=0.03 ; X^{2}=22.96\right)$ was observed in the overall Brucella infection rates. In villages of Yoko, the highest Brucella infection rate of $23.52 \%$ was observed in animals of Kong and the lowest rate of $7.1 \%$ in those of Megan. Between villages of Yoko, no significant difference $\left(P=0.35 ; X^{2}=5.52\right)$ was observed in the overall Brucella infection rates.

The Brucella infection rate was $20.93 \%$ [95\% Cl: 17-24.95] in cattle and 10.79\% [95\%Cl: 7.45-15.08] sheep. This infection rate was significantly high $\left(P<0.0001 ; X^{2}=14.71\right)$ in cattle $(20.93 \%$; $[95 \% \mathrm{Cl}$ : $17.43-24.95])$ than sheep $(10.79 \%$; $[95 \% \mathrm{Cl}$ : 7.45-15.08]) (Table 1).

\section{Prevalence of Brucella abortus and Brucella melitensis according to animal species}

From the 159 animals found with Brucella infections, the AMOS-PCR targeting $B$. abortus and $B$. melitensis revealed 12.93\% [95\% Cl: $10.71-15.49$ ] with B. abortus infections and 3.17\% [95\%Cl: $2.04-4.43$ ] with B. melitensis (table 1). Of the 125 cattle reported with Brucella infections, 112 (89.6\%) were infected by B. abortus and 10 (8.0\%) by B. melitensis. The remaining five (2.4\%) animals found with Brucella infections were probably carriers of other Brucella species that have not been investigated in this study. Between the infection rates of $B$. abortus and $B$. melitensis, significant difference $\left(P \otimes 0.001, X^{2}=95.81\right)$ was observed in cattle. From 34 sheep found with Brucella infections, $6(17.6 \%)$ were infected by $B$. abortus and $19(55.9 \%)$ by $B$. melitensis; giving thus the infection rate of $1.9 \%(6 / 315)$ and $6.03 \%(19 / 315)$ for $B$. abortus and $B$. melitensis respectively. Between the infection rates of $B$. abortus and $B$. melitensis, significant difference $\left(P=0.008, \mathrm{X}^{2}=7.04\right)$ was also observed in sheep.

The $B$. abortus infection rate was significantly higher $\left(P \otimes 0.0001 ; X^{2}=51.98\right)$ in cattle $(18.76 \% ;[95 \% \mathrm{Cl}: 15.45-22.57])$ than sheep (1.9\%; [95\% Cl: $0.69-4.14])$ (Table1). Regarding $B$. melitensis, its infection rate was significantly higher $(P$ $\left.=0.0004, X^{2}=12.73\right)$ in sheep (6.03\%; [95\% Cl: 3.63-9.41]) than cattle (1.67\%; [95\%Cl: 0.08-3.08]) (table 1). Amongst the 159 domestic animals found with Brucella infections, 9 (5.6\%) were co-infected by $B$. abortus and B. melitensis while 130 (81.71\%) were single infections of $B$. abortus (68.55\%: 109/159) or B. melitensis (12.57\%: 20/159).

\section{Prevalence of Brucella abortus and Brucella melitensis according to sampling sites}

Of the 43 animals found with Brucella infections at Yoko, 33 (76.7\%) harbored B. abortus and 8 (18.6\%) B. melitensis, giving thus an overall infection rate of $9.48 \%$ (33/348) for $B$. abortus and $2.29 \%(8 / 348)$ for $B$. melitensis respectively. Between the infection rates of $B$. abortus and $B$. melitensis, significant difference $\left(P<0.001 ; X^{2}=16.21\right)$ was observed at Yoko. However, no significant difference was observed between villages of this locality neither for the overall infection rate of $B$. abortus $\left(P=0.05, \mathrm{X}^{2}=10.84\right)$ nor for $B$. melitensis $\left(P=0.7 ; \mathrm{X}^{2}=3.002\right)$ (Table 2$)$. In animals of Yoko, the highest infection rate of $23.52 \%$ [95\% Cl: $6.41-60.24$ ] for $B$. abortus was found at Kong and the lowest rate of $4.2 \%$ [95\% Cl: 0.08-12.52] at Megan.

From 116 animals reported with Brucella infections in the Noun division, 85 (73.3\%) were due to B. abortus and 21 (18.1\%) to B. melitensis. This gives the overall infection rates of $15.07 \%(85 / 564)$ for $B$. abortus and $3.71 \%(21 / 564)$ for B. melitensis. Between these two Brucella species, significant difference $\left(P<0.001 ; X^{2}=0.00\right)$ was observed in their infection rates in the Noun division. The overall $B$. abortus infection rates vary significantly $\left(P=0.04, X^{2}=16.34\right)$ 
between villages of this locality. The highest $B$. abortus infection rate of $21.42 \%$ was found at Magba followed by $20.57 \%$ at Foumban. The $B$. melitensis infection rates vary between villages of the Noun division with the highest rate (9.18\%) at Magba. Between villages of the Noun division, no significant difference $\left(P=0.106 ; X^{2}=13.17\right)$ was observed in the $B$. melitensis infection rates (Table 2).

In general, the $B$. abortus infection rate varies within and between the two localities (Table 2). The infection rate of $15.07 \%$ [95\% Cl: $12.04-18.64$ ] reported for $B$. abortus in the Noun division was significantly higher $\left(P=0.014, X^{2}=5.96\right)$ than the $9.48 \%$ [95\% Cl: 6.52-13.31] recorded at Yoko (Table 2). Between Yoko and the Noun division, no significant difference $\left(P=0.23 ; X^{2}=1.42\right)$ was observed for the $B$. melitensis infection rates. No $B$. mellitensis infection was recorded in animals of Malentouen of the Noun division, Kong and Megan of Yoko (table 2).

\section{Discussion}

During the last decades, several investigations have been undertaken to determine the sero-prevalence of Brucella antibodies in sub-Saharan African countries $[7,10,11,13,14]$. Although most of these investigations demonstrated contacts between Brucella and various hosts including humans and different animal species, the identity of bacteria species that are responsible for the production of Brucella' antibodies has not been deeply investigated. To fill these gaps, molecular tools were used to determine the prevalence of $B$. abortus and $B$. melitensis in cattle and sheep of southern Cameroon.

The low Brucella infection rate of $17.43 \%$ obtained in this study is lower that $35 \%$ reported in India [22]. This could be explained by some variations of environmental factors and livestock management systems which are risk factors for brucellosis transmission [32]. The significant $\left(P<0.0001 ; X^{2}=14.71\right)$ high Brucella infection rate in cattle $(20.93 \%)$ compared to sheep $(10.79 \%)$ is consistent with results reported in South Africa where more cattle were found with Brucella infections than sheep [23]. This high infection rate could result from the larger herd sizes of cattle and their management system $[5,33]$. Indeed, the extensive cattle management system and the larger size of herds have been reported as risk factors for brucellosis [34]. Moreover, the relative short life expectancy of sheep compared to cattle is additional factor explaining the low Brucella infection rate in sheep. In fact, cattle remain in the herd for many years and therefore, are more exposed to Brucella infections than sheep. This hypothesis is in agreement with previous observations reporting that as long as infected animals remain in contact with the rest of the herd, the number of infected animals will increase [10, 35, 36, 37].

The identification of $B$. abortus and $B$. melitensis in both cattle and sheep corroborates results obtained in Tanzania and Uganda $[7,21]$. Remarkably, the $B$. abortus infection rate was significantly higher $\left(P<0.0001 ; X^{2}=53.54\right)$ in cattle (18.76\%) compared to sheep $(1.9 \%)$ while $B$. melitensis was significantly $\left(P=0.0004 ; X^{2}=26.58\right)$ more prevalent in sheep $(6.03 \%)$ than cattle $(1.67 \%)$. These results could be explained by the fact that $B$. abortus and $B$. melitensis are the main etiologic agents of brucellosis in cattle and sheep, respectively [38]. Our results showing high $B$. abortus infection rate in cattle are in agreement with those previously reported in Asia and other African countries where $B$. abortus was more prevalent in cattle $[7,17,22,38]$. Moreover, $B$. abortus has been reported as the most commonly Brucella species that has been isolated and characterized in cattle from sub-Saharan countries [13]. The high $B$. melitensis infection rate in sheep is also consistent with observations reporting this bacteria species as the most prevalent in sheep in most sub-Saharan countries [13]. Compared to $B$. abortus, the low B. melitensis infection rate in domestic animals suggests low transmission of $B$. melitensis in sub Saharan countries [39]. Known as the etiologic agent of brucellosis in sheep [13], the small size of sheep' herd compared to cattle is another factor playing for the low transmission of $B$. melitensis and consequently, its low infection rate in domestic animals [11, 27]. 
The identification of $B$. abortus in sheep and $B$. melitensis in cattle is not common because these animals are not their main hosts. Nevertheless, it is important to point out that several isolates of $B$. abortus have been obtained from milk and abortion products of sheep and goat $[40,41]$; highlighting the probability of sheep to be infected by $B$. abortus. In addition, other animal species like sheep has been reported to be susceptible to $B$. abortus infections [42, 43]. The detection of $B$. melitensis in cattle is in agreement with previous observations reporting the transmission of $B$. melitensis to cattle $[44,45]$. The cross-transmission of $B$. abortus to sheep and $B$. melitensis to cattle could be explained by the fact that these animals share the same environment. As these animals live and share together the same breeding sites in villages of Yoko and the Noun division, the transmission of $B$. melitensis to cattle and $B$. abortus to sheep can therefore occur. This hypothesis is strengthened by previous observations reporting the transmission of $B$. melitensis to cattle, especially where both cattle and small ruminants share the same breeding sites $[44,45]$. Indeed, the presence of larger herds and livestock production system that put together, and in the same place, cattle, goat and sheep favor inter and intra-specific transmission of different Brucella species $[5,33,46]$. The animals found with Brucella infections, but for which $B$. abortus and $B$. melitensis have not been identified were certainly infected by other Brucella species. Searching for other Brucella species, like for instance B. ovis which is a non-zoonotic bacteria species that is restricted to sheep, will be of great interest, especially because its existence has been reported in sub-Saharan countries [47, 48, 49].

While no significant difference $\left(P=0.35 ; \mathrm{X}^{2}=5.52\right)$ was observed in the overall Brucella infection rates between villages of Yoko, significant difference $\left(P=0.003 ; X^{2}=22.96\right)$ was reported between villages of the Noun division; highlighting some variations in the Brucella infection rates according to sampling sites. This could result from variations of environmental factors and/or livestock management system that may have impacts on the transmission pattern of different Brucella species.

Although significant differences were reported in the $B$. abortus infection rates in villages of the two localities, no significant difference $\left(P=0.23 ; X^{2}=1.42\right)$ was observed for $B$. melitensis neither in villages of Yoko nor in those of the Noun division. These results suggest that the infection rates of $B$. melitensis do not seem to vary with the sampling sites. This could be explained by the low size of herds and the limited movement of sheep. In such context, it is likely that the transmission of $B$. melitensis from infected to uninfected sheep is limited because animals of different herds cannot mix together and most of time, sheep are regularly sale and killed for different ceremonies. The situation is completely different for $B$. abortus because its infection rates vary significantly $\left(P=0.014 ; \mathrm{X}^{2}=5.96\right)$ between villages of the two localities (Table 2). These results suggest high transmission of $B$. abortus in some villages like Kong in Yoko, Foumban, Magba, Bangourain and Koutaba in the Noun division. These villages can be considered as hot spots where particular attention must be paid during the implementation of control measures. They are also of great epidemiological interest for further investigations on human brucellosis. The reasons explaining the high infection rate, and probably the high transmission of $B$. abortus in these villages are not well understood. However, we can speculate about: i) the large size of herds in these villages, ii) the environmental factors that could be more favorable for brucellosis transmission, iii) the poor cattle management systems, iv) the regular mixing of animals from different herds. Most of these factors have been recognized as important contributors for the transmission and the spread of brucellosis in livestock $[25,46,50]$. Viewed the high prevalence of $B$. abortus recorded in these villages and the zoonotic nature of this bacterium, measures should be taken to prevent the transmission of $B$. abortus to humans.

Results of this study highlight the need to raise awareness for brucellosis control and to design control measures that could be implemented to fight this neglected zoonotic disease. While waiting for investigations that will enable to identify the risk factors responsible for the transmission of brucellosis in villages showing high Brucella infection rates, the feeding and management systems must be improved; the sharing of common grazing areas as well as the mixing of animals of different herds must be limited because these factors have been recognized elsewhere as risk factors for brucellosis transmission [51, 52, 53]. 
The main limitations of this study rely on the fact that no Brucella species was isolated and characterized. In consequence, the genetic structure of Brucella circulating within and between the two localities remains unknown. Moreover, all Brucella species for which cattle and sheep are susceptible have not been investigated and consequently, other Brucella species that could be found in animals of Yoko and the Noun division remain also unknown. With these limitations, the transmission dynamics within and between villages, and also between different animal species is not well understood for efficient planning of control operations against brucellosis.

\section{Conclusion}

This study revealed the presence of B. melitensis and B. abortus in cattle and sheep of villages of Yoko and the Noun division of southern Cameroon. Results of this study enabled to identify villages showing high risk for Brucella infections and where control operations could be implemented. They highlight the need of developing control measures to fight Brucella infections. The identification of $B$. melitensis and $B$. abortus, which are zoonotic bacteria, suggests investigations on human brucellosis, especially in villages showing high risk for Brucella infections. Such investigations could help to design control measures for both human and animal brucellosis.

\section{Declarations}

\section{Ethics approval and consent to participate}

The protocol of this study was approved by the Ministry of livestock, fisheries and animals Industries of Cameroon with the reference number Ref $N^{\circ} 015 / 16 /$ L/DDEPIA.NN. The local administrative and traditional authorities of each sampling site were also informed and gave their approval. Subsequently, the review board of the molecular parasitology and entomology subunit of the Department of Biochemistry of the Faculty of Science of the University of Dschang gave its approval. Verbal consent was obtained from each owner, after detailed explanation of the objective of the study.

\section{Consent for publication}

Not applicable

\section{Availability of data and materials}

All data generated and/or analyzed are included in this article.

\section{Competing interests}

The authors declare that they have no competing interests.

\section{Funding}

This work was supported by the University of Dschang of Cameroon through the Molecular Parasitology and Entomology subunit of the Faculty of Science. 


\section{Authors' contributions}

KNRM helped in the sample collection, identification of Brucella species and the drafting of the manuscript. SAB participated in the collection of samples, the study design and the drafting of the manuscript. FO helps in the collection of samples. GS participated in the conception, data collection and the drafting of the manuscript. All authors read and approved the final version of the manuscript.

\section{Acknowledgements}

We are grateful for the support of inhabitants of different localities as well as the staff of different divisional delegations of the Ministry of livestock, fisheries and animals Industries of Cameroon. We also thank the anonymous reviewers for helpful comments on the manuscript

\section{Authors' Information}

1: Molecular Parasitology and Entomology Unit, Department of Biochemistry, Faculty of Science, University of Dschang, PO. Box 67, Dschang, Cameroon. 2: University of Bamenda, Cameroon.

\section{References}

1. Corbel M, Leberg S, Cosivi O. Brucellosis in humans and animals. Geneva: WHO/CDS/EPR/2006.7:Available:http://www.who.int/csr/resources/publications/Brucellosis.pdf. Accessed: 15 february 2020.

2. Akakpo, A. J., A. Têko-Agbo, and P. Koné. The Impact of Brucellosis on the Economy and Public Health in Africa. Compendium of Technical Items Presented to the OIE World Assembly of Delegates or to OIE Regional Commissions, 2010; 71-84.

3. Michaux-charachon, Sylvie, Vincent Foulongne, David O. Callaghan, and Michel Ramuz. Brucella à I ' Aube Du Troisième Millénaire: Organisation Du Génome et Pouvoir Pathogène. Pathol Biol 2002; 50: 401-412.

4. Corbel, M.J. Brucellosis: an overview. Emerging Infectious Diseases. 1997; 3: 213-221.

5. Ariza, Javier, Mile Bosilkovski, Antonio Cascio, Juan D. Colmenero, Michael J. Corbel, Matthew E. Falagas, Ziad A. Memish, Mohammad Reza, Hasanjani Roushan, Ethan Rubinstein, Nikolaos V Sipsas, Javier Solera, Edward J. Young, and Georgios Pappas. Perspectives for the Treatment of Brucellosis in the 21st Century: The loannina Recommendations. PLoS Med. 2007; 4(12): 4 e317.

6. Nielsen, K. and Yu Wl. serological diagnosis of brucellosis. Contributions, Sec. Biol. Med. Sci. 2010; 89: 65-89.

7. Assenga, Justine A., Lucas E. Matemba, Shabani K. Muller, Joseph J. Malakalinga, and Rudovick R. Kazwala. Epidemiology of Brucella Infection in the Human , Livestock and Wildlife Interface in the Katavi-Rukwa ecosystem, Tanzania. BMC Veterinary Research 2015;11: 1-11.

8. Godfroid,J., Scholz,H., Barbier, T.,Nicolas,C., Wattiau, P.,Fretin, D.,\& Moriyon, I. Brucellosis at the animal/ecosystem/human interface at the beginning of the 21st century. Preventive Veterinary Medicine. 2011; 102(2): 118-131. 
9. Mangen, M.J., Pfeiffer, D., Chilonda, P. Bovine Brucellosis in Sub-Saharan Africa: Estimation of Meat and Milk off Take Potential. 2002; Available: www.fao.org/3/a-ag274e.pdf. Accessed: 15 february 2020.

10. Madut, Nuol Aywel, Adrian Muwonge, George William Nasinyama, Bwalya Muma, Jacques Godfroid, Ambrose Samuel Jubara, James Muleme, and Clovice Kankya. The Sero-Prevalence of Brucellosis in Cattle and Their Herders in Bahr El Ghazal Region, South Sudan. BMC Infectious Diseases. 2018; 19:450.

11. Awah-Ndukum, J., Mouiche, M.M., Bayang, H.N., Ngu Ngwa, V., Assana, E., Feussom, K.J.M., Manchang, T.K., \& Zoli, P.A. Factors of Brucellosis among Indigenous Cattle in the Adamawa and North Regions of Cameroon. Journal of Hindawi Veterinary Medicine International, 2018. https://doi.org/10.1155/2018/3468596

12. Awah-ndukum, Julius, Mohamed Moctar, Mouliom Mouiche, Lucy Kouonmo-ngnoyum, Houli Nicolas Bayang, Tanyi Kingsley Manchang, Rodrigue Simonet, et al. Seroprevalence and Risk Factors of Brucellosis among Slaughtered Indigenous Cattle, Abattoir Personnel and Pregnant Women in Ngaoundéré, Cameroon. BMC Infectious Diseases. 2018; 18: 611 1-13.

13. Ducrotoy, M., Bertu, W.J., Matope, G., Cadmus, S., Conde-Álvarez, R., Gusi, A.M., Welburn, S., Ocholi, R., Blasco, J.M., \& Moriyón, I. Brucellosis in Sub-Saharan Africa: Current challenges for management, diagnosis and control. Acta Tropica, 2017; 165: 179-193.

14. Mazeri S., Scolamacchia F., Handel, Kenton, I.G., Morgan, L.V.N., Tanya, B.M., \& De Bronsvoort, C. Risk factor analysis for antibodies to Brucella, Leptospira and C. burnetii among cattle in the Adamawa Region of Cameroon: a crosssectional study. Tropical Animal Health and Production. 2012; 45: 617-623.

15. Bovine brucellosis, In: Manual of Diagnostic Tests and Vaccines for Terrestrial Animals. 2013; pp.1-35.

16. Kaynak-Onurdag, F; Okten, S and Sen, B. Screening Brucella spp. in bovine raw milk by real-time quantitative PCR and conventional methods in a pilot region of vaccination, Edirne, Turkey. Dairy Sci. 2016; 99: 3351-3357.

17. Karthik, K., P. Thomas, Elamurugan Appavoo, Tamil Nadu Veterinary, and Arun Remesh. Serological and Molecular Detection of Brucella Abortus from Cattle by RBPT, STAT and PCR, and Sample Suitability of Whole Blood for PCR. Asian Journal of Animal and Veterinary Advances. 2014; 9 (4): 352-359.

18. Wang, Ying, Zhanli Wang, Yaxian Zhang, Liyun Bai, Yue Zhao, Chunfang Liu, An Ma, and Hui Yu. Polymerase Chain Reaction - Based Assays for the Diagnosis of Human Brucellosis. Annals of Clinical Microbiology and Antimicrobials 2014;13 (31): 1-8.

19. Mahajan, V.; Banga, H. ; Filia, G.; Gupta, M. P. and Gupta, K. Comparison of Diagnostic Tests for the Detection of Bovine Brucellosis in the Natural Cases of Abortion. IJVR, Vol. 2017; 18 (3): 183-189.

20. Mitka, Stella, Constantine Anetakis, Efımia Souliou, Eudoxia Diza, Athina Kansouzidou, and J. C. L. I. N. M. Icrobiol. Evaluation of Different PCR Assays for Early Detection of Acute and Relapsing Brucellosis in Humans in Comparison with Conventional Methods. journal of clinical microbiology. 2007; 45 (4):1211-1218.

21. Hoffman, Tove, Kim Rock, Denis Rwabiita, and Shaman Muradrasoli. Molecular Detection and Characterization of Brucella Species in Raw Informally Marketed Milk from Uganda. Infection Ecology and Epidemiology. 2016; 6: 32442

22. Khamesipour, Faham, Abbas Doosti, and Shahrekord Branch. Molecular Detection of Brucella Spp. in the Semen, Testis and Blood Samples of Cattle and Sheep Molecular Detection of Brucella Spp . in the Semen , Testis and Blood Samples of Cattle and Sheep. journal of pure and applied microbiology. 2013; 7: 495-500.

23. Caine Lesley-Anne, Uchechukwu Uchechukwu Nwodo, Anthony Ifeanyin Okoh, Ezekiel Green. Molecular characterization of Brucella species in cattle, sheep and goats obtained from selected municipalities in the Eastern Cape, South Africa. Asian Pac J Trop Dis 2017; 7(5): 293-298.

24. Betty, Maphuti, Ledwaba Id, Calvin Gomo, Kgaugelo Edward Lekota, Philippe Le, Ayesha Hassim, Gilles Vergnaud Id, and Henriette Van Heerden. Molecular Characterization of Brucella Species from Zimbabwe. PLoS Negl Trop Dis. 2019; 13(5): e0007311.

Page $11 / 16$ 
25. Motta, Paolo, Thibaud Porphyre, Saidou M. Hamman, Kenton L. Morgan, Victor Ngu Ngwa, Vincent N. Tanya, Eran Raizman, Ian G. Handel, and Barend Mark Bronsvoort. Cattle Transhumance and Agropastoral Nomadic Herding Practices in Central Cameroon. BMC Veterinary Research. 2018;14: 214.

26. Seignobos, C. La Question mbororo. Réfugiés de la RCA au Cameroun, Yaoundé/Paris (HCR/SCAC/IRD) 2008.

27. Bayemi, P. H., G. D. Mah, K. Ndamukong, V. M. Nsongka, I. Leinyuy, H. Unger, N. M. Ndoumbe, E. C. Webb, M. D. Achukwi, F. Hakoue, and N. D. Luogbou. Bovine Brucellosis in Cattle Production Systems in the Western Highlands of Cameroon. Int J Animal Biology. 2015; 1(2):38-44.

28. Thrusfield M., Blackwell Science Ltd, a Blackwell, Veterinary epidemiology, Oxford, UK 2007; 610.

29. Asgedom H., D. Damena, and R. Duguma. Seroprevalence of bovine brucellosis and associated risk factors in and around Alage district, Ethiopia, SpringerPlus. 2016; 5 (1):

30. Navajas, M., Lagnel, J., Gutierrez, J., Bourset, P. Species wide homogeneity of nuclear ribosomal ITS2 sequences in the spider mite Tetranychus urticae contrasts with extensive mitochondrial COI polymorphism. Heredity. 1998; 80: $742-752$

31. Bricker, Betsy J. and Shirley M. Halling. Melitensis, Brucella Ovis, and Brucella Suis Bv . 1 by PCR. J Clin Microbiol. J Clin Microbiol. 1994; 32 (11): 2660-6.

32. Gul, S.T., Khan, A., Rizvi, F., \& Hussain, I. Sero-prevalence of brucellosis in food animals in the Punjab, Pakistan. Pakistan Veterinary Journal. 2014; 34: 454-458.

33. Mohamed, Eman Mohamed-ahmed, Abdelhamid Ahemd, Mohamed Elfadil, and Enaam Mohamed El-sanousi. Seroprevalence and Risk Factors of Caprine Brucellosis in Khartoum State, Sudan. Veterinary World, 2018; 223 (11):511-518.

34. Kaindi, D. W., Schelling, E, Wangoh J. M., Imungi, J. K., Farah, Z. and Meile, L.. Risk factors for symptoms of gastrointestinal illness in rural town Isiolo, Kenya. Zoonoses Public Health. 2012; 59 (2):118-125.

35. Radostits, O.M., Gay, C.C., Blood, D.C., Hinchcliff, K.W., Chapter18, Diseases associated with bacteria-III. In: Veterinary Medicine: A Textbook of the Disease of Cattle, Sheep, Pigs, Goats and Horses, 9th ed. W.B. Saunders Company Ltd., Sydney, 2000; 963-994.

36. Radostits, O.M., Gay, C.C., Blood, D.C. and Hinchcliff, K.W. Disease caused by Brucella spp. A Textbook of the Disease of Cattle, Sheep, Pigs, Goats and Horses. 10th ed. ELBS Bailliere Tindall, London, UK 2007; 870-871.

37. Kelly, Robert F., Saidou M. Hamman, Kenton L. Morgan, Egbe F. Nkongho, Ngu Ngwa, Vincent Tanya, Walters N. Andu, Melissa Sander, Lucy Ndip, G. Handel, Stella Mazeri, Adrian Muwonge, and Barend M. De C. Bronsvoort. Knowledge of Bovine Tuberculosis, Cattle Husbandry and Dairy Practices amongst Pastoralists and Small-Scale Dairy Farmers in Cameroon. PLoS ONE. 2016; 11(1): e0146538.

38. McDermott, J., Grace, D., Zinsstag, J. Economics of brucellosis impact and control in low-income countries. Sci. Tech. 2013; 32: 249-261.

39. Acha, N.P., Szyfres, B., Zoonoses and Communicable Diseases Common to Man and Animals, third ed., vol. 1. Pan American Health Organization (PAHO), Washington, DC. 2003.

40. Okoh, A.E. An investigation of abortion in sheep in Rano L.I.B.C. near Kano, Nigeria. Anim. Health Prod. Afr. 1980; 28: 135-138.

41. Bertu, W.J., Ducrotoy, M.J., Mu noz, P.M., Mick, V., Zú niga-Ripa, A., Bryssinckx, W., Kwaga, J.K.P., Kabir, J., Welburn, S.C., Moriyón, I., Ocholi, R.A. Phenotypic and genotypic characterization of Brucella strains isolated from autochthonous livestock reveals the dominance of B. abortus biovar 3a in Nigeria. Microbiol. 2015; 180(1-2):103-8.

42. Aparicio, E. Díaz. Epidemiology of Brucellosis in Domestic Animals Caused by Brucella Melitensis , Brucella Suis and Brucella Abortus. sci. tech. Off. int. Epiz., 2013;32 (1): 53-60. 
43. Lilenbaum, W., G.N. De Souza, P. Ristow, M. Cortez, M. Cortez Moreira, S. Fráguas, V. da Silva Cardoso, and W. Martin Roland Oelemann. A serological study on Brucella abortus, caprine arthritis-encephalitis virus and Leptospira in dairy goats in Rio de Janeiro, Brazil. The Vet. J. 2007; 173: 408-412.

44. Benkirane, A. Ovine and caprine brucellosis: world distribution and control/eradication strategies in West Asia/North Africa region. Small Rumin. Res. 2006; 62: 19-25.

45. Refai, M. Incidence and control of brucellosis in the Near East region. Microbiol. 2002; 90: 81-110.

46. Musallam, Imadidden, Andrée Prisca, Damitoti Yempabou, Cha-ah Crystella Ngong, Müller Fotsac, Mohamed-moctar Mouiche-mouliom, Jean Marc, Kameni Feussom, Jean Bosco, Désiré Ntakirutimana, Adama Fane, Elisabeth Dembele, Adama Doumbia, Amah Akpemdo, Paul-henri Siméon Ayih-akakpo, Pindemnewe Pato, Magnoudewa Pali, Arnaud S. R. Tapsoba, Germaine Minougou, Haladou Gagara, Aïda Issaka, Bhagyalakshmi Chengat, Laura Craighead, Emi Takahashi, John Mcgiven, Patrick Nguipdop-djomo, Punam Mangtani, Rrianatou Alambédji-bada, Ayayi Justin, and Javier Guitian. Acta Tropica Brucellosis in Dairy Herds: A Public Health Concern in the Milk Supply Chains of West and Central Africa. Acta Tropica. 2019; 197:105042.

47. Van Rensburg, S.W., Van Heerden, K.M., Le Roux, D.J., Snyders, A.J., van Heerden, K.M., Infectious infertility in sheep. S. Afr. Vet. Assoc. 1958; 29: 223-233.

48. Cameron, R.D., Carles, A.B., \& Lauerman, L.H.J. The incidence of Brucella ovis in some Kenya flocks and its relationship to clinical lesions and semenquality. Veterinary Record, 1971; 89: 552-557.

49. Ate, I.U., Bello, A., Nenshi, P.M., Allam, L. Rashidat, M. Foetal maceration associated with Brucella ovis infection in a Yankassa ewe. REDVET Rev. Electron. Vet. 2011;12: 1-6.

50. Motta, P., Porphyre, T., Handel, I., Hamman, S.M., Ngu Ngwa, V., Tanya, V., Morgan, K., Christley, R., Bronsvoort, B.M. Implications of the cattle trade network in Cameroon for regional disease prevention and control. Sci Rep. 2017; 7: 43932.

51. Fèvre, E.M., Bronsvoort, B.M.d.C., Hamilton, K.A., Cleaveland, S., Animal movements and the spread of infectious diseases. Trends in Microbiology. 2006; 14: 125- 131.

52. Awa, Daniel Ndzingu and Mbunkah Daniel Achukwi. Livestock Pathology in the Central African Region: Some Epidemiological Considerations and Control Strategies. Animal Health Research Reviews. 2010; 11(2): 235-244.

53. Volkova, Victoriya V, Richard Howey, Nicholas J. Savill, and Mark E. J. Woolhouse. Sheep Movement Networks and the Transmission of Infectious Diseases." PLOS ONE 2010; 5(6): e11185.

\section{Tables}

Table 1: Prevalence of Brucella abortus and Brucella melitensis according to animal species $\begin{array}{llllllll}\text { Animal } & N & \text { Brucella genus (\%) } & 95 \% C I & \begin{array}{l}\text { B. } \\ \text { abortus (\%) }\end{array} & \text { 95\% CI } & \begin{array}{l}\text { B. } \\ \text { melitensis }\end{array} & \begin{array}{l}95 \% \\ \text { CI }\end{array}\end{array}$

$(\%)$

\begin{tabular}{|c|c|c|c|c|c|c|c|}
\hline Cattle & 597 & $125(20.93)$ & $17-24.95$ & $112(18.76)$ & $\begin{array}{l}15.45- \\
22.57\end{array}$ & $\begin{array}{l}10 \\
(1.67)\end{array}$ & $0.08-3.08$ \\
\hline Sheep & 315 & $34(10.79)$ & $7.45-15.08$ & $6(1.9)$ & $0.06-4.14$ & $\begin{array}{l}19 \\
(6.03)\end{array}$ & $3.63-9.41$ \\
\hline Total & 912 & $159(17.43)$ & $\begin{array}{l}14.83- \\
20.36\end{array}$ & $118(12.93)$ & $\begin{array}{l}10.71- \\
15.49\end{array}$ & $\begin{array}{l}29 \\
(3.17)\end{array}$ & $2.13-4.56$ \\
\hline$X^{2}$ & & 14.71 & & 51.98 & & 12.73 & \\
\hline$P$ value & & $0.0001 *$ & & $0.0001 *$ & & $0.0004^{*}$ & \\
\hline
\end{tabular}


N: number of animal tested; CI: Confidence interval; (\%): Brucella infection rate; *significance difference

Table 2: Prevalence of Brucella abortus and Brucella melitensis according to sampling sites and villages 


\begin{tabular}{|c|c|c|c|c|c|c|c|c|}
\hline sites & Villages & $\mathbf{N}$ & Brucella ssp (\%) & $95 \%$ & B. abortus (\%) & $95 \%$ & B. melitensis (\%) & $95 \%$ \\
\hline & & & & CI & & CI & & CI \\
\hline \multirow[t]{9}{*}{ Yoko } & Lena & 50 & $5(10)$ & $\begin{array}{l}3.24- \\
23-33\end{array}$ & $3(10)$ & $\begin{array}{c}1.23- \\
17.53\end{array}$ & $2(4)$ & $\begin{array}{l}0.48- \\
14.44\end{array}$ \\
\hline & Ngoun & 100 & $17(17)$ & $\begin{array}{l}9.9- \\
27.22\end{array}$ & $14(17)$ & $\begin{array}{c}7.65- \\
23.49\end{array}$ & $3(3)$ & $\begin{array}{l}0.06- \\
8.76\end{array}$ \\
\hline & Yoko wankou & 40 & $6(15)$ & $\begin{array}{l}5.5- \\
32.65\end{array}$ & $5(12.5)$ & $\begin{array}{l}4.06- \\
29.17\end{array}$ & $1(2.5)$ & $\begin{array}{l}0.00- \\
13.92\end{array}$ \\
\hline & Megan & 70 & $5(7.1)$ & $\begin{array}{l}2.31- \\
66\end{array}$ & $3(4.2)$ & $\begin{array}{c}0.08- \\
12.52\end{array}$ & $0(0.00)$ & 1 \\
\hline & Kong & 17 & $4(23.52)$ & $\begin{array}{l}6.41- \\
60.24\end{array}$ & $4(23.52)$ & $\begin{array}{l}6.41- \\
60.24\end{array}$ & $0(0.00)$ & l \\
\hline & Kounde & 71 & $6(8.4)$ & $\begin{array}{l}3.1- \\
18.39\end{array}$ & $4(7.04)$ & $\begin{array}{l}1.53- \\
14.42\end{array}$ & $2(2.81)$ & $\begin{array}{l}0.03- \\
10.17\end{array}$ \\
\hline & Total & 348 & $43(12.35)$ & $\begin{array}{l}8.9- \\
16.64\end{array}$ & $33(9.48)$ & $\begin{array}{c}6.52- \\
13.31\end{array}$ & $8(2.29)$ & $\begin{array}{l}00.99- \\
4.53\end{array}$ \\
\hline & $x^{2}$ & & 5.52 & & 10.84 & & 3.002 & \\
\hline & $\mathrm{P}$ value & & 0.35 & & 0.05 & & 0.70 & \\
\hline \multirow[t]{12}{*}{ Noun } & Foumban & 73 & $21(28.76)$ & $\begin{array}{l}17.81- \\
43.97\end{array}$ & $15(20.54)$ & $\begin{array}{c}11.5- \\
33.89\end{array}$ & $4(5.47)$ & $\begin{array}{l}1.4- \\
14.03\end{array}$ \\
\hline & Foumbot & 56 & $11(19.64)$ & $\begin{array}{l}9.81- \\
35.15\end{array}$ & $9(16.07)$ & $\begin{array}{c}7.35- \\
30.51\end{array}$ & $1(1.78)$ & $\begin{array}{l}0.00- \\
9.94\end{array}$ \\
\hline & Njimom & 46 & $9(19.56)$ & $\begin{array}{l}7.71- \\
34.27\end{array}$ & $6(13.04)$ & $\begin{array}{l}4.79- \\
28.39\end{array}$ & $1(2.17)$ & $\begin{array}{l}0.00- \\
12.11\end{array}$ \\
\hline & Massangam & 62 & $9(14.51)$ & $\begin{array}{l}6.64- \\
27.56\end{array}$ & $6(9.6)$ & $\begin{array}{l}3.55- \\
21.06\end{array}$ & $1(1.61)$ & $\begin{array}{l}0.00- \\
8.98\end{array}$ \\
\hline & Magba & 98 & $28(28.57)$ & $\begin{array}{l}18.99- \\
41.29\end{array}$ & $21(21.42)$ & $\begin{array}{l}13.26- \\
32.76\end{array}$ & $9(9.18)$ & $\begin{array}{l}4.19- \\
17.43\end{array}$ \\
\hline & Malentouen & 51 & $0(0.00)$ & l & $0(0.00)$ & I & $0(0.00)$ & l \\
\hline & Bangourain & 71 & $17(23.94)$ & $\begin{array}{l}13.95- \\
38.34\end{array}$ & $13(18.30)$ & $\begin{array}{l}9.75- \\
31.31\end{array}$ & $2(2.81)$ & $\begin{array}{l}0.03- \\
10.17\end{array}$ \\
\hline & Kouptamo & 56 & $9(16.07)$ & $\begin{array}{l}7.35- \\
30.51\end{array}$ & $7(12.5)$ & $\begin{array}{c}5.03- \\
25.75\end{array}$ & $1(1.78)$ & $\begin{array}{l}0.00- \\
9.94\end{array}$ \\
\hline & Koutaba & 51 & $12(23.52)$ & $\begin{array}{l}12- \\
41.1\end{array}$ & $8(15.68)$ & $\begin{array}{l}6.77- \\
30.91\end{array}$ & $2(3.92)$ & $\begin{array}{l}0.00- \\
10.92\end{array}$ \\
\hline & Total & 564 & $116(20.56)$ & $\begin{array}{l}17- \\
24.67\end{array}$ & 85 (15.07) & $\begin{array}{c}12.04- \\
18.64\end{array}$ & $21(3.71)$ & $\begin{array}{l}2.30- \\
5.69\end{array}$ \\
\hline & $\mathrm{x}^{2}$ & & 22.96 & & 16.34 & & 13.17 & \\
\hline & $P$ value & & $0.003 *$ & & $0.04 *$ & & 0.106 & \\
\hline Total & & 912 & $159(17.43)$ & $\begin{array}{l}14.83- \\
20-36\end{array}$ & $118(12.93)$ & $\begin{array}{l}10.71- \\
15.49\end{array}$ & $29(3.17)$ & $\begin{array}{l}2.13- \\
4.56\end{array}$ \\
\hline $\mathrm{X}^{2}$ & & & 10.07 & & 5.96 & & 1.42 & \\
\hline $\mathrm{P}$ value** & & & $0.0015^{*}$ & & $0.014 *$ & & 0.23 & \\
\hline
\end{tabular}


N: number of animal tested; CI: Confidence interval; (\%): Brucella infection rate; *significance difference; **: P values resulting from the comparison of infection rates between Yoko and Noun.

\section{Figures}

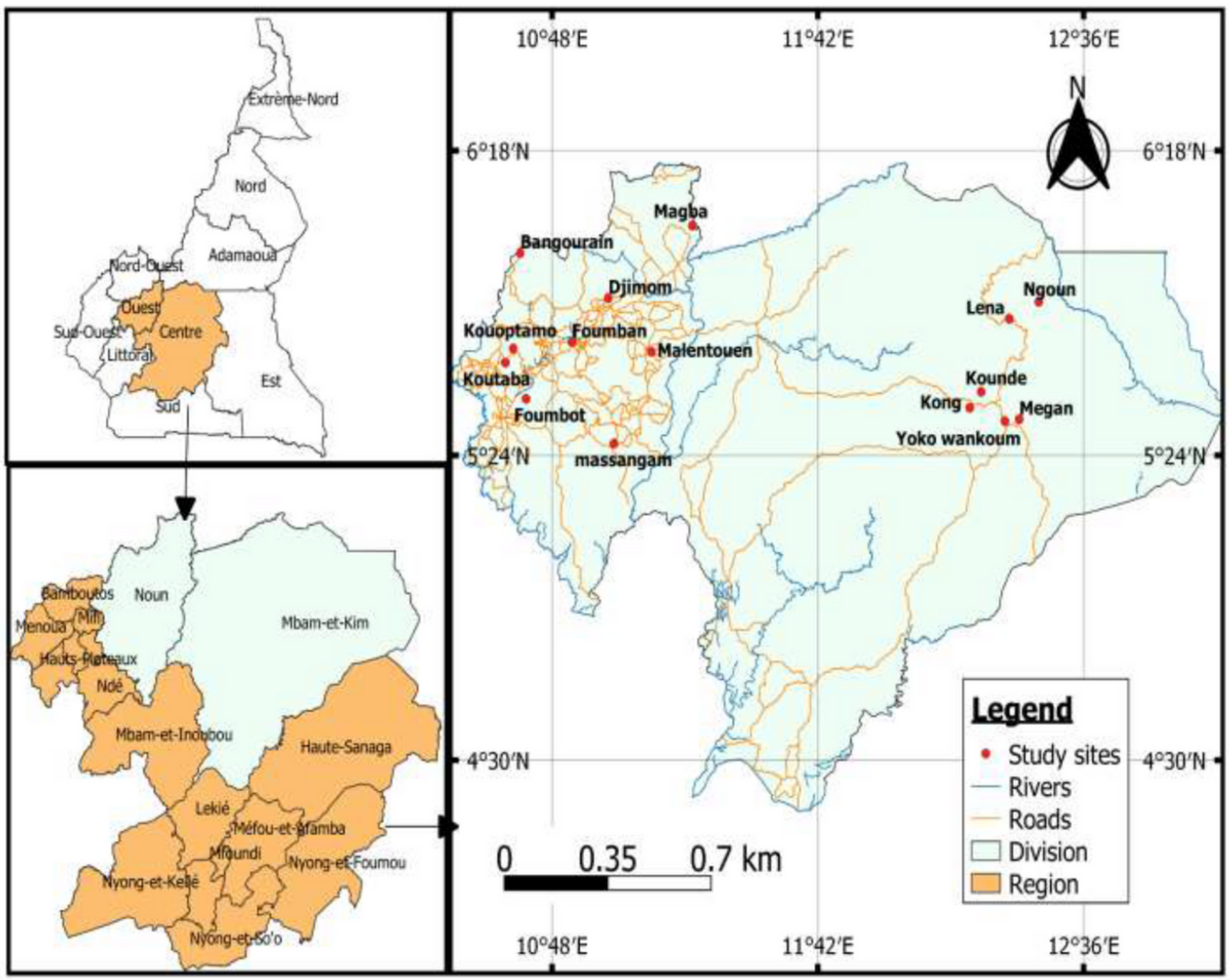

Figure 1

Map showing villages where animals were sampled 